\title{
THE RUSSIAN FEDERATION ENERGY POLICY, AN INSTRUMENT FOR RECONSOLIDATING THE STATUS OF HIGH POWER
}

\author{
Lt.Col.Assoc.Prof. Andi Mihail BĂNCILĂ, PhD*
}

\begin{abstract}
The disintegration of the USSR in December 1991 marked the end of the Cold War. Many foreign policy analysts were quick to point out that Russian Federation had ceased to be a threat to the Western world. Despite facing a multitude of economic, social and military problems, under the leadership of Vladimir Putin the Russian state managed to be reborn. Russian Federation's miraculous return was made possible by the successful implementation of a policy of economic centralization that overlapped with a period of rising global oil prices. Economic prosperity encouraged the Russian Federation government to return to the old practices of the Soviet period, succeeding in unbalancing the fragile states of Eastern Europe and once again endangering the peace of the entire continent.
\end{abstract}

Keywords: Russian Federation; Cold War; Crimea; hydrocarbons; conflict.

Even though, by the end of the $20^{\text {th }}$ century, most politicians and academics saw Russian Federation as an old great power incapable of honoring its commitment on a global scale, the beginning of the 21 st century gives us a very different picture of the initial perception. To understand Russian Federation's positioning in a multipolar world and its evolution in the first half of the 21st century, we must examine carefully the path it has taken over the past 500 years. It is interesting to note that the sinuous evolution of Russian Federation makes it difficult for specialists who try to anticipate its future course. During this time, the Russian State behaved atypically in relation to the experience of any other great power, managing to be reborn after each limit situation it had been through.

\section{Soviet heritage}

With the dissolution of the former Soviet Empire, Russian Federation became the natural heir of the most important elements of its heritage (nuclear weapons and its place in the UN Security Council ${ }^{1}$ ). The huge nuclear arsenal deployed during the Cold War both in Soviet territory and in some European States was withdrawn by important international agreements on Russian Federation territory ${ }^{2}$. In the first phase of this process, many negotiations took place between Russia and the

\footnotetext{
*"Ferdinand I" Military Technical Academy e-mail: bancila.andi@gmail.com
}

former republics of Ukraine, Kazakhstan, and Belarus, which wanted to preserve part of this arsenal on their territory. Being aware of the risk of nuclear proliferation, the United States supported the total withdrawal of these weapons in Russian Federation and, through the Memorandum signed in Budapest on 5 December $1994^{3}$, they guaranteed territorial integrity to the former Soviet republics and support in the event of a violation of its agreements ${ }^{4}$.

From an economic point of view, Russia remained the main power of the former Soviet Empire, having direct or indirect access to most mineral resources. The Russian State ranks first in the world in the natural gas production and eighth in oil production ${ }^{5}$, a position it merges by controlling deliveries of these resources extracted from the Central Asian States (the oil and gas pipelines that served the deposits of these states were interconnected only with the Russians, with no alternative for their export). Even though the role of coal has decreased in the functioning of new industrial capacities, from an energy point of view, it continues to play a key role. Russian Federation has had the second-largest coal reserve in the world, which, along with its hydropower potential, makes it the world's fourth-largest producer of electricity ${ }^{6}$. With the help of Gazprom, which exploits 94\% of the country's natural gas resources ${ }^{7}$ and holds significant stakes in European companies, Russian Federation has put European states in trouble whenever its geopolitical interests have called for 
it. The interruption of natural gas supplies in winter or even the total cessation of exports to some states have become common practice. In this way, the Russian Federation managed to obtain numerous economic or even political concessions. Very few oil-dependent states have taken a firm stand when the Kremlin political leader deliberately violated existing international treaties and regulations. There are even situations in which some European leaders such as the Prime Minister of Hungary, Victor Orban, have indirectly supported certain Russian Federation initiatives ${ }^{8}$.

\section{Energy resources - the main asset of Russian Federation foreign policy}

Russia's post-cold war era proved to be winding, and the periods of normalization, escalation, and crisis in its relations with other members of the international community varied considerably. After the disappearance of the USSR, the Russian State went through a strong political and economic crisis which affected its international credibility. After the failed privatizations of the 1990s, many factories closed their doors, firing millions of Russians. The only areas that theoretically could still benefit were energy companies, which unfortunately had been taken over by an interest group known as oligarchs (former prominent members of the CPSU or secret services). The main financial losses weakened the centralized leadership and allowed these "investors" to govern the regions in which they operated, sometimes challenging Moscow leadership.

The attempt by the European States to emancipate themselves from Russian Federation energy control has proved difficult. In the early 1990s, the West supported a project aimed at liberalizing the exploitation of Russian energy resources ${ }^{9}$. On 12 May 1993, by Government Resolution No. 354, the two major state oil companies Yuganskneftegaz (which produce $11 \%$ of the oil extracted from Russian Federation) and Kuybyshevnefteorgsentez (extracting 9\% of Russian Federation's oil) were merged into a single company Yukos ${ }^{10}$ which, in 1996, was sold to Mikhail Khodorkovsky. The man behind this enterprise gained in very little time or impressive power, allowing him to influence many aspects of the Russian state's economic policies. At its peak, the Yukos produced $20 \%$ of Russian oil and could decide where and at what price to sell products, sometimes the political decisions of the Russian government. This company can theoretically deliver its products to Western markets without responding to the Kremlin's orders. Aware of the risk of market liberalization, Vladimir Putin's new political leadership nationalized these companies. The movement of centralization of energy production began on 25 October 2003, with the arrest of the Russian oligarch for tax evasion. He was accused of embezzling the state with several billions of dollars, in 2004 his fortune was estimated by Forbes at about 15 billion US dollars ${ }^{11}$.

To reduce the losses of large companies, the Moscow government, under the new leader Vladimir Putin, has nationalized or increased its participation in many of the country's large energy companies. This, together with a period of rising oil prices, has allowed Russian Federation to reconsider its position at the table of great powers and come back into force to regain some of its former sphere of influence. Although initially political and economic analysts had serious doubts about Russian Federation's acceptance into the elite club of the world's most industrialized states, since 1997 it has been accepted in the G7 group which has become the $G 8^{12}$ since then.

The restoration of Russian Federation's monopoly on its energy resources has given the new Kremlin leader Vladimir Putin the leverage necessary to regain high power. Because of their monopoly on the European energy market, negotiations on technology and additional funding for new investments have been difficult. This has forced the Western States to identify a new way of reducing energy dependence on Russian Federation ${ }^{13}$. Politicians have sought to promote a series of projects by which they would reduce dependence on resources imported from this state. Many funds have been earmarked for the development of the alternative energy sector (wind, solar, hydropower, etc.). In an ambitious medium- and long-term plan, the European Union intends to reduce the amount of $\mathrm{CO}_{2}$ released into the atmosphere by $40 \%$ by 2030 and to increase the percentage to $60 \%$ by $2050^{14}$.

This aim cannot have immediate effects, so European countries need to develop other energy strategies. They also approved the allocation of funds for the construction of terminals for imports of liquefied natural gas to be used for imports of gas from Norway, Qatar and shale gas extracted 
from the United States ${ }^{15}$. The most accessible and efficient project, achievable in a short time, was the construction of a network of pipelines competing with those of the Russian Federation, through which cheap natural gas could have been imported from central Asia. The construction of the Nabucco project, which is supposed to deliver cheap gas from the Caspian Sea ${ }^{16}$, to Europe, became the EU's zero priority and a series of impact assessments have been commissioned. The $3,900 \mathrm{~km}$ long pipeline was to be a joint project of Turkey, Bulgaria, Romania, Hungary and Austria, which, through national companies, should have monitored a percentage of future business ${ }^{17}$. Azerbaijan, Turkmenistan and Kazakhstan should have become major suppliers of European countries that could have benefited from natural gas at competitive prices.

Unfortunately, thisapproachwas easilycanceled by Gazprom, which began the construction of two new competing North and South Stream projects, in which it could attract from the beginning several key Nabucco States (Bulgaria and Hungary), and the largest consumer of natural gas, Germany. Also, Russian Federation ensured that Georgia, one country on whose territory a significant part of the pipeline was to be built, goes bankrupt and even lose its sovereignty over important areas of its territory. Russian rulers reactivated one conflict frozen in the 90s and threw the State into an infinite civil war. In 2008, troops of the Russian Federation intervened directly against the Georgian State, tearing two autonomous republics of Abkhazia and Southern Ossetia ${ }^{18}$, thus indefinitely delaying the construction of the pipeline.

Russian Federation 's energy strategy has proved much more complex, considering many other options. From the very first moment, it adopted the decision to build a pipeline system to bypass the territory of Ukraine, and Russian Federation has tried to win the goodwill of some States of the European Union. The Russian geopolitical game was indirectly supported by Germany, which became the main importer and distributor of Russian gas later, two companies registered in that state became partners of the North Stream project (Wintershall Holdings and E.ON Ruhrgas owned $15.5 \%$ of the project $)^{19}$. The other Member States of the European Economic Area took part in this project by participating with their energy companies in the pipeline's construction and benefiting from significant benefits. Netherlands and France, represented by N.V. Nederlandse Gasunie and GDF Suez S. A., were registered as project partners and were rewarded with $9 \%$ of the actions $^{20}$.

The strategic acquisitions allowed the Russian state to obtain even the indirect control of project Nabucco's future, through Gazprom Russia controls $30 \%$ of Austrian packet, named Baumgarten and $20 \%$ of Centrex Europe Strategy company, which were to be involved in the construction of the future pipeline ${ }^{21}$. In case Nabucco would become a reality, Russian companies already control directly or indirectly the Azerbaijan's gas production, purchasing with an overstated price the exploitation from Shah Deniz with a confirmed capacity of 15 billions of cubic meters every year ${ }^{22}$. Even more, Russia has secured an important part of the route of the future pipeline, concluding strategic partnerships with a part of Central Europe states. Hungary has become one of the main partners of the Russian state in this geographic area, benefiting of deliveries of natural gas at preferential prices and substantial gains resulting from the privatization of the state oil company MOL (through the company Surgutneftegaz, Russian Federation bought at a double price, compared to the listing on the stock exchange, an important package of actions of Hungarian company ${ }^{23}$ ).

\section{Political blackmail and military intervention, an important part of Russian Federation diplomacy}

Even though Russian Federation managed to keep much of the international privileges of the former USSR, its geopolitical position has deteriorated significantly, especially as a result of the loss of territories that ensured the access to the planet's ocean. Russian Federation's exit to the Baltic Sea was reduced to only 6 nautical miles ${ }^{24}$ wide lane near Saint Petersburg and another small part in the area of Kaliningard enclave, where most of the Baltic fleet was deployed (coastal areas adjacent to the former republics of Lithuania, Latvia and Estonia, and Finland had requested the rising of territorial water's limits from 4 so 12 nautical miles). Russian Federation also lost most of its exit to the Black Sea in favor of Ukraine and Georgia, including the Crimean Peninsula which had been transferred by CPSU Secretary General 
Nikita Khrushchev (Ukrainian in origin) in 1954 to the Soviet Socialist Republic of Ukraine ${ }^{25}$. The Black Sea fleet has been divided between the three successor states of the USSR, Russian Federation winning almost $70 \%$ of its ships. Because most of the port infrastructure was located in Crimea, in Sevastopol the two states signed a treaty allowing the Russian navy to stay in this port until $2017^{26}$. Taking advantage of the installation in the presidential chair in Kiev of the pro-Russian Victor Ianukovici, in 2010 Russia renegotiates the agreement to extend stationary of Russian troops for another 25 years.

The issue of the Russian navy stationed in Sevastopol is being re-discussed after the overthrow of the president Viktor Ianukovici and the installation in Kiev of a pro-Western government ${ }^{27}$. Ukraine initiated association and later accession talks to the two Euro-Atlantic structures NATO and EU. This severely disturbed the Kremlin leadership, which considered unacceptable the idea of having such a directly long ${ }^{28}$ border line with the competing collective security organization. Russian Federation's response was not left waiting for long; with the voice of president Putin a hypothesis was launched that the border was guaranteed to another state, not to the one that asserted itself after the movement known as the Euromaidan ${ }^{29}$.

Even though after the dismemberment of the former USSR the international prestige of Russia had decreased significantly, the vast majority of international organizations created and coordinated by Moscow (Warsaw Pact, CAER) had dissolved, and the third world states revolving around it had sought new protectors, slowly but surely, Russian Federation managed to return to the table of great powers. Efforts to regain political and economic influence, including within the former Soviet empire, were significant.

On December 8, $1991^{30}$, shortly before the collapse of the former USSR, the Kremlin leadership set up a new economic cooperation organization called the Commonwealth of Independent States. The most likely source of inspiration had been the British Commonwealth, which had sought to preserve the single market of its former colonial empire. The CIS (Commonwealth of Independent States) ${ }^{31}$ had to play the role of a common market for the states from the former Soviet empire.
This organization was initially joined by 11 of the 15 former members of the USSR, to which Georgia ${ }^{32}$ was added in December 1993 (the exceptions were the Baltic states, which had begun negotiations for their Euro-Atlantic integration). As in the case of the single market of the former British Empire, the CIS encountered great difficulties in functioning, especially as a result of the competition that other great powers had created in this space. Many of the Soviet enterprises operating with subassemblies produced throughout the former USSR diversified their suppliers and indirectly bankrupted some of the economic actors they traditionally ${ }^{33}$ worked with. Morally used Soviet technology was replaced by the one produced in the West or in the South Asian states, with Russian Federation remaining a mere supplier of raw materials. Also in this interval, the Soviet economy suffered due to the loss of control of important energy suppliers in the Central Asian states. Initially, oil and gas producers in Kazakhstan, Turkmenistan and Uzbekistan depended on transport infrastructure located on Russian territory. This benefited the Russian Federation, which could set the selling price of these products. Over time, China, directly interested in the exploitation of existing gas and oil in this area, invested considerable sums and created a system of pipelines that connected it directly to the oil fields of these states ${ }^{34}$.

Another sign of the Russian Federation's weakness in relation to its former Cold War competitor, the United States, was the loss of military outposts in territories considered to be of strategic importance to its national security. This happened not only in the territory of Eastern European states, but also in the territory of some former Soviet republics. The Baltic States were the first entities to express their desire to detach themselves politically and economically from the former USSR. In 2004 the three former republics joined NATO and the $\mathrm{EU}^{35}$, later managing to build a separate road from Moscow. Less well known to the public is the fact that Russian Federation's economic and military weakness in the 90 s allowed the United States to move significantly closer to the oil area around the Caspian Sea.

After the outbreak of the globalwaragainst terror in 2001, the United States showed its willingness to cooperate with them in order to develop its own energy or military infrastructure. In this respect, the 
US government approved several loans to Central Asian states, with Uzbekistan receiving 160 million dollars and Kyrgyzstan about 92 million $^{36}$ dollars. This gesture was not disinterested, as the US government was interested in developing a network of military bases around Afghanistan at the time. The United States negotiated several agreements with these states that would require the temporary installation of the US military in bases near the area of operations in Afghanistan. In 2002, the US military deployed about 2,000 soldiers to the Karshi-Khanabad military base in Uzbekistan. Under a similar agreement, Kyrgyzstan agreed to host up to 2,000 troops at an air base in Manas near the capital, Bishkek ${ }^{37}$, while all other former Soviet republics in the area had agreed to allow overflight of U.S. military aircraft.

The U.S. military in Afghanistan and neighboring states near the Russian Federation border grew rapidly, from about 25,000 troops in 2000 before the outbreak of the war on terror to no less than 80,000 a few years later $^{38}$. The Russian authorities interpreted that as an attempt to encircle the oil area (the US military presence in the Persian Gulf had been established since the early 1990s following the conflict with Iraq), position from which the US could subsequently launch a military attack against any state or non-state entity that could have endangered its interests.

\section{Conclusions}

Russia's political instability ended with the coming to power of former KGB agent Vladimir Putin. With the help of people from the intelligence and public order structures, he restored the Russian Federation government's control over all regions of the state and the country's most important companies. Through a particularly violent military action, Putin managed to pacify the Caucasus (ended the war in Chechnya) and directly supported the separatist movements in the former Soviet republics. The rich mineral resources to which the Russian state had access were a great geopolitical advantage. Through them, they were able to put pressure and obtain important concessions from European states and China.

Recovering even part of its revenues, Russia re-launched a series of military actions outside the national territory both within the former Soviet empire and at a great distance from its borders.
The most important conflicts assumed totally or only partially by Moscow were those in Syria and Ukraine. In 2014, Russia launched the most controversial political action since the post-Soviet era by invading part of its territory in neighboring Ukraine and producing the annexation of the Crimean province. This incident significantly contributed to the suspension of the Russian state from the $G 8^{39}$ forum and the imposition of economic sanctions by the US and major EU Member States.

The military and political actions taken by this great power will continue to attract the attention of Western decision-makers and raise concerns among the governments of neighboring states.

\section{NOTES:}

1 Blum Yehuda, "Russia Takes over the Soviet Union's Seat at the United Nations", European Journal of International Law, Volume 3, Issue 2, 1992, p. 354

2 William Walker, "Nuclear Weapons and the Former Soviet Republics", International Affairs, Volume 68, Issue 2, April 1992, p. 256.

3 https://web.archive.org/web/20140317182201/ http://www.cfr.org/arms-control-disarmament-and-nonpro liferation/budapest-memorandums-security-assurances1994/p32484\#, accessed on 28.02.2019.

4 The fulfillment of the conditions set out in the memorandum signed in Budapest, also undertaken by Great Britain, China, and France, was invoked by the Ukrainian State when the undeclared conflict with the Russian Federation led to the loss of Crimea in 2014. The provisions of the treaty were also recalled to the international community at the outbreak of the secessionist conflict in the eastern part of the country, where the Ukrainian state again accused Russia of interfering in the country's internal affairs.

5 Constantin Hlihor, Security policy in the contemporary international environment: energy sector, European Institute Publishing House, Iași, 2008, p. 103

6 M. Luzhikova, Energy Security in Russia Federation apud I. Chifu, A. Sauliuc, B. Nedea (ed.), Energy security strategies in the wider Black Sea Region, Curtea Veche Publishing House, Bucharest, 2010, p. 243.

7 Lars Petter Lundena, Daniel Fjaertofta, Indra Overland, Alesia Prachakova, "Gazprom vs. other Russian gas producers: The evolution of the Russian gas sector", Energy Policy No. 61, 2013, p. 663.

$8 \mathrm{https} / / / \mathrm{www}$. euractiv.com/section/politics/news/ hungarys-orban-defends-russia-cooperation-at-putinvisit/?fbclid=IwAR1Yc6W98EnP-e2h4j31stFLQsi_ntrCmA K80nAEBqY1J0_8QIBj96jKGPo, accessed on 29.02.2020.

9 Constantin Hlihor, op.cit., p. 131.

10 Sim Li-Chen, The Rise and Fall of Privatization in the Russian Oil Industry, Palgrave Macmillan, New York, 2008, p. 51.

11 Marshall Goldman, "Putin and the Oligarchs", Foreign Affairs, Vol. 83, No. 6 (Nov. - Dec., 2004), p. 34, https://www.jstor.org/stable/20034135 
12 On 24 March 1014, the Russian Federation was suspended from the G8 because of armed aggression against Ukraine, which led to the annexation of the Crimean peninsula. Smale Alison, Shear, Russia is ousted from group of 8 by US and Allies, The New York Times, March 24, 2014, https:/www.nytimes.com/2014/03/25/world/europe/obamarussia-crimea.html, accessed on 26.06.2020.

13 Alexander Ghaleb, Natural gas as an instrument of Russia state power, US Army War College. Retrieved, 2011, p. 20, http://www.jstor.org/stable/resrep11537, accessed on 27.01.2021.

14 Rihard Morningstar, Andras Simonyi, Olga Khakova, Irina Markina, European Energy Diversification: How Alternative Sources, Routes, and Clean Technologies Can Bolster Energy Security and Decarbonization, Atlantic Council Global Energy Center, 2020, p. 2, https://www.jstor. org/stable/, accessed on 27.01.2021.

15 https://ec.europa.eu/commission/presscorner/detail/ es/IP 19 1531, accessed on 27.01.2021.

16 Stefanova Boyka, "European Strategies for Energy Security in the Natural Gas Market", Journal of Strategic Security, Vol. 5, No. 3, Fall 2012, p. 58, https://www.jstor. org/stable/26463950, accessed on 28.01.2021.

17 Ibidem, p. 59.

18 David Matsaberidze, "Russia vs. EU/US through Georgia and Ukraine", Connections, Vol. 14, No. 2, Spring 2015, p. 82, https://www.jstor.org/stable/26326399, accessed on 28.01.2021.

19 http://www.nord-stream.com/en/the-pipeline/factsfigures.html, accesed on 28.01.2021.

20 Ibidem.

21 M. Luzhikova, op.cit., p. 259.

22 Ibidem.

23 George Mihailov, Rolul Turciei în securitatea energetică europeană, apud Dan Dungaciu, Darie Cristea (ed.), Doctrine, strategii, politici. De la discursul geopolitic la operaționalizarea securității internaționale, Publishing House of The Institutute for Political Sciences and International Relations, Bucharest, 2012, p. 238.

24 Sergiu Tămaș, Geopolitica, Publishing House of The Institute for Social Theory, Bucharest, 1999, p. 265.

25 Scânteia No. 2908, 28 februarie 1954.

26 In 1997, the presidents of the two states signed the Friendship Agreement between Ukraine and the Russian Federation, which regulated this issue. The agreement was renewed in 2010 by President Medvedev, who extended his stay for another 25 years in exchange for significant price reductions for Russian gas delivered to Kiev.

27 Roy Allison, "Russian 'deniable' intervention in Ukraine: how and why Russia broke the rules", International Affairs, 90: 6, 2014, p. 1257.

28 The Russian Federation already has a direct border with two NATO member states (Poland and Lithuania) in the area of the Kaliningrad enclave.

$29 \mathrm{https} / /$ warontherocks.com/2015/06/the-budapestmemorandum-and-the-russia-ukraine-crisis/, accessed on 28.01.2020.

30 http://webarchive.loc.gov/all/20060720175013/ http://www.therussiasite.org/legal/laws/CISagreement.html, accessed on 28.01.2020.
31 The CIS was born on December 8, 1991 by signing the Belavezha agreement. Under this treaty, it was decided that as of December 26, 1991, the USSR would cease to function as a state. After the disintegration of the USSR for a time, the former Central Asian republics continued to revolve around Moscow, on which they continued to depend for technological imports and transport infrastructure of the main exported products, oil and natural gas. As they had been given the necessary conditions to strengthen their own economies through direct exports of natural gas and oil, they sought new opportunities to emancipate themselves from Moscow.

32 Zbigniew K Brzezinski, Russia and the Commonwealth of Independent States: Documents, Data, and Analysis, Routledge, New York, 2015, p. 238, https://books.google.ro/ books?hl, accessed on 09.02.2021.

33 Robert Strayer, Why Did the Soviet Union Collapse? Understanding Historical Change, M.E. Sharpe, New York, 1998, p. 134, https://books.google.ro/books?hl, accessed on 09.02.2021.

34 In 2003, with the economic and technological support of China, Kazakhstan managed to inaugurate the first $448 \mathrm{~km}$ of oil pipeline that Russia no longer directly controls. In 2011, the length of this pipeline exceeded $2798 \mathrm{~km}$, ensuring for the first time the total economic independence of the Central Asian states. See Kazakhstan-China Crude Oil Pipeline, https:// www.hydrocarbons-technology.com/projects/kazakhstanchina-crude-oil-pipeline/, accessed on 26.06.2019.

35 Jurkynas Mindaugas, Security concerns of the Baltic States in the twenty first century, p. 113, apud Clive Archer, Alyson J.K. Bailes, Anders Wivel, Small States and International Security: Europe and Beyond, Routledge, New York, 2014, https://books.google.ro/books?, accessed on 11.02.2021.

36 Paul Dobrescu, Geopolitics, Communication Publishing House, Bucharest, 2003, p. 312.

37 Douglas Schorzman, "Staging Base for Afghan War Handed Over to Kyrgyzstan", The New York Times, June2,2014, https:/www.nytimes.com/2014/06/04/world/ asia/staging-base-for-afghan-war-is-handed-to-kyrgyzstan. html, accessed on 26.06.2020.

38 Paul Dobrescu, op.cit., p. 311.

39 Alison Smale, Michael Shear, "Russia Is Ousted From Group of 8 by U.S. and Allies", New York Times, March 24 2014, https://www.nytimes.com/2014/03/25/world/europe/ obama-russia-crimea.html, accessed on 05.10.2020.

\section{REFERENCES}

Archer Clive, Bailes J.K. Alyson, Wivel Anders, Small States and International Security: Europe and Beyond, Routledge, New York, 2014.

Blum Yehuda, "Russia Takes over the Soviet Union's Seat at the United Nations", European Journal of International Law, Volume 3, Issue 2, 1992.

Boyka Stefanova, "European Strategies for Energy Security in the Natural Gas Market", Journal of Strategic Security, Vol. 5, No. 3, Fall 2012. 
Chifu I., Sauliuc A., Nedea B. (ed.), Energy security strategies in the wider Black Sea Region, Editura Curtea Veche, Bucharest, 2010.

Dobrescu Paul, Geopolitics, Communication Publishing House, Bucharest, 2003.

Dungaciu Dan, Cristea Darie (ed.), Doctrine, strategii, politici. De la discursul geopolitic la operaționalizarea securității internaționale, Publishing House of the Institutute for Political Sciences and International Relations, Bucharest, 2012.

Ghaleb Alexander, Natural gas as an instrument of Russia state power, US Army War College. Retrieved, 2011.

Goldman Marshall, "Putin and the Oligarchs", Foreign Affairs, Vol. 83, No. 6, Nov. - Dec. 2004.

Hlihor Constantin, Security policy in the contemporary international environment: energy sector, European Institute Publishing House, Iași, 2008.

Lars Petter Lundena, Fjaertofta Daniel, Overland Indra, Prachakova Alesia, "Gazprom vs. Other Russian gas producers: The evolution of the Russian gas sector", Energy Policy, No. 61, 2013.

Matsaberidze David, "Russia vs. EU/US through Georgia and Ukraine", Connections, Vol. 14, No. 2, Spring 2015.

Morningstar Rihard, Simonyi Andras, Khakova Olga, Markina Irina, European Energy Diversification: How Alternative Sources, Routes, and Clean Technologies Can Bolster Energy Security and Decarbonization, Atlantic Council Global Energy Center, 2020.

Roy Allison, "Russian 'deniable' intervention in Ukraine: how and why Russia broke the rules", International Affairs, 90: 6, 2014.

Schorzman Douglas, Staging Base for Afghan War Handed Over to Kyrgyzstan, The New York Times, June 2, 2014.

Sim Li-Chen, The Rise and Fall of Privatization in the Russian Oil Industry, Palgrave Macmillan, New York, 2008.
Smale Alison, Shear Michael, "Russia Is Ousted From Group of 8 by US and Allies", New York Times, March 24, 2014.

Strayer Robert, Why Did the Soviet Union Collapse? Understanding Historical Change, M.E. Sharpe, New York, 1998.

Tămaș Sergiu, Geopolitica, Publishing House of The Institute for Social Theory, Bucharest, 1999.

Walker William, "Nuclear Weapons and the Former Soviet Republics", International Affairs, Volume 68, Issue 2, April 1992.

Zbigniew K. Brzezinski, Russia and the Commonwealth of Independent States: Documents, Data, and Analysis, Routledge, New York, 2015.

https://www.hydrocarbons-technology.com/ projects/kazakhstan-china-crude-oil-pipeline https://warontherocks.com/2015/06/the-buda pest-memorandum-and-the-russia-ukraine-crisis/

http://webarchive.loc.gov/

all/20060720175013/http://www.therussiasite.org/ legal/laws/CISagreement.html

http://www.nord-stream.com/en/the-pipeline/ facts-figures.html

https://ec.europa.eu/commission/presscorner/ detail/es/IP_19_1531

https://www.nytimes.com/2014/03/25/world/ europe/obama-russia-crimea.html,

https://web.archive.org/web/20140317182 201/http://www.cfr.org/arms-control-disarm ament-and-nonproliferation/budap est-memora ndums-security-assurances-1994/p32484\#,

https:/www.euractiv.com/section/politics/ news/hungarys-orban-defends-russia-cooperationat-putin-visit/ffbclid=IwAR1Yc6W98EnP-e2h4j31stFLQ si_ntrCmAK80nAEBqY1J0_8QIBj96jKGPo

https://warontherocks.com/2015/06/the-buda pest-memorandum-and-the-russia-ukraine-crisis/ 